\title{
ENUCLEAÇÃO DE CISTO DO DUCTO NASOPALATINO E IMPLANTE EM MESMA SESSÃO
}

Ricardo Iwao TAKEUCHI; Matheus Sabóia MARCONDES; Nelson Luis Barbosa REBELLATO; Delson João da COSTA; Paulo Roberto MÜLLER.

O cisto do ducto nasopalatino é a variedade mais comum de cistos fissurais, originando-se de restos epiteliais aprisionados durante o desenvolvimento do conducto nasopalatino, podendo abranger toda a sua extensão. São descobertos exclusivamente nos exames radiográficos como área radiolúcida, redonda ou oval, de bordos bem definidos e localizados na linha média. Normalmente são assintomáticos a não ser que sofram infecção secundária, apresentam pequenas dimensões não existindo relatos de transformações malignas, o que justifica apenas a proservação, quando indicada, a remoção cirúrgica deve ser procedida. Os autores descrevem um caso de cisto do ducto nasopalatino em paciente do sexo feminino, leucoderma, 30 anos, saudável, no qual foi indicada a remoção cirúrgica devido à necessidade da instalação de implante osteointegrável na região de incisivo central ausente. Foi realizada a cirurgia de enucleação do cisto sob anestesia local e preenchimento da cavidade com osso autógeno removido do ramo mandibular e imediata instalação do implante osteointegrável. Após um ano do procedimento cirúrgico, observou-se na região do cisto, característica a qual sugere um processo de remodelação do enxerto ósseo empregado e sucesso na estabilidade do implante, conseguindo suprir a necessidade estética e funcional causada pela ausência do incisivo central. 